\title{
Whistleblowing in the Irish Military: the Cost of Exposing Bullying and Sexual Harassment
}

John Hogan

Technological University Dublin, john.hogan@tudublin.ie

Sharon Feeney

Technological University Dublin, sharon.feeney@tudublin.ie

Grace Flynn

Technological University Dublin, Grace.flynn@tudublin.ie

Follow this and additional works at: https://arrow.tudublin.ie/buschmarart

Part of the Defense and Security Studies Commons

\section{Recommended Citation}

Flynn, G., Hogan, J. and Feeney, S. (2019). Whistleblowing in the Irish Military: the cost of exposing bullying and sexual harassment.' Journal of Military Ethics, 18(2), pp. 129-144. doi:10.1080/

15027570.2019 .1650454

This Article is brought to you for free and open access by the School of Marketing at ARROW@TU Dublin. It has been accepted for inclusion in Articles by an authorized administrator of ARROW@TU Dublin. For more information, please contact arrow.admin@tudublin.ie, aisling.coyne@tudublin.ie,gerard.connolly@tudublin.ie.

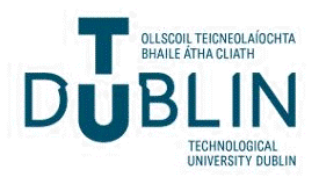




\section{Whistleblowing in the Irish Military: The Cost of Exposing Bullying and Sexual Harassment}

\section{Grace Flynn, John Hogan \& Sharon Feeney}

To cite this article: Grace Flynn, John Hogan \& Sharon Feeney (2019) Whistleblowing in the Irish Military: The Cost of Exposing Bullying and Sexual Harassment, Journal of Military Ethics, 18:2, 129-144, DOI: $10.1080 / 15027570.2019 .1650454$

To link to this article: https://doi.org/10.1080/15027570.2019.1650454

曲 Published online: 16 Aug 2019.

Submit your article to this journal

山 Article views: 69

Q View related articles $₫$

View Crossmark data $\asymp$ 


\title{
Whistleblowing in the Irish Military: The Cost of Exposing Bullying and Sexual Harassment
}

\author{
Grace Flynn ${ }^{a}$, John Hogan ${ }^{b}$ and Sharon Feeney ${ }^{b}$ \\ ${ }^{a}$ College of Business, Dublin Institute of Technology, Dublin, Ireland; ${ }^{b}$ College of Business, Technological \\ University Dublin, Dublin, Ireland
}

\begin{abstract}
Whistleblowing has gained increasing media attention over the past 40 years, as incidents of abuse and wrongdoing associated with businesses, religious institutions, the media and politics have come to light. In this article, we investigate the consequences of a military whistleblower's actions for both himself and the military institution that he was a part of. The case concerns former army officer Dr. Tom Clonan and his findings concerning the bullying and sexual harassment of female personnel in the Irish Defence Forces at the turn of the century. As these revelations came to light over 17 years ago we are able to examine their consequences for the military since that time.
\end{abstract}

\section{KEYWORDS}

Whistleblower; military;

Ireland; bullying; harassment

I swore an Oath of Allegiance to the Irish Constitution as an Army Officer. I did not swear loyalty to a bunch of sexist bullies at the Defence Forces Headquarters. (Tom Clonan)

\section{Introduction}

Inappropriate behaviour in the workplace is not a new phenomenon: blowing the whistle on such behaviour is less common. Those inside an organisation can witness inappropriate behaviour on a first-hand basis, and consequently are best placed to raise concerns. However, few do so, as inevitably, they can also have the most to lose by exposing such behaviour.

Nevertheless, whistleblowers are significant players in the modern world (Devine and Maassarani 2011). Whistleblowers and their struggles to reveal corruption have become part of popular culture in films, such as Serpico - about New York police officer Frank Serpico; The Insider - about Brown and Williamson vice president Jeffrey Wigand; and North Country - about iron miner Lois E. Jenson (Carroll and Buchholtz 2014). There have been countless books, documentaries and reports on whistleblowers and whistleblowing. The concept has also attracted increasing academic attention since the 1970s (see Jubb 1999; Miceli and Near 1984; Miceli, Near, and Dworkin 2008; Nader, Petkas, and Blackwell 1972).

CONTACT John Hogan john.hogan@TUDublin.ie College of Business, Technological University Dublin, Office 3062, Aungier Street, Dublin, Ireland; Sharon Feeney sharon.feeney@TUDublin.ie $\mathbf{E}$ College of Business, Technological University Dublin, Office 5055, Aungier Street, Dublin, Ireland

This article is dedicated to the memory of Prof. Amr Arisha, a valued friend and colleague, missed by all. 
In this paper, we examine an incidence of whistleblowing related to the bullying and sexual harassment of female personnel in the Irish military, which occurred just after the turn of the century. Our aim is to explore the motives of the whistleblower, exarmy officer Dr. Tom Clonan, the challenges and hardships he faced and the practical consequences his actions have had for the Defence Forces. In this, we will see how the military initially responded by retaliating against the whistleblower, but subsequently recognised that there were serious organisational problems having to do with bullying and sexual harassment and set about resolving these. The findings highlight the benefits for the military and wider Irish society of Clonan's actions, but also the costs for himself, his career and his family.

\section{The evolution of whistleblowing}

The term whistleblowing first came into popular parlance during the 1970s when Ralph Nader, a United States (US) civic activist, coined the term for his activities (Vandekerckhove 2010; Tracy 2006). In the past, citizens who reported misconduct were often labelled "rats", "snitches" or "traitors" (Barrera and Hughes 2014). However, during the 1970s Nader succeeded in turning the label whistleblower into a positive word. Nader described a "whistleblower" as someone of high ethical values and honesty, who will sacrifice to report illegal actions (Barrera and Hughes 2014).

The 1972 publication of the report from a conference on "Professional Responsibility", organised by Nader, has become a noted document in discussing the concept of corporate whistleblowing (Bjørkelo and Madsen 2013). By the mid-1970s, the topic was gaining increasing attention (Crowther and Capaldi 2008). However, most whistleblowing research in the 1970s focused on government rather than private organisations (Crowther and Capaldi 2008). This was the decade of well-known whistleblowers W. Mark Felt, Frank Serpico, Frank Snepp and John Stockwell (Payne 2013).

In the 1980s, Anderson et al. (1982) famously looked at whistleblowing in the Bay Area Rapid Transit (BART) project in San Francisco. Miceli and Near (1984) observed 8,500 employees to investigate if employees who report malpractice differ from those who do not. Glazer and Glazer (1989) conducted a study of the belief systems of whistleblowers and how they cope with retaliation. These studies all argued that there was a necessity for whistleblowers "in a complex technological and bureaucratic world" (Glazer and Glazer 1989, 79).

The following decades saw the widespread adoption in various countries of legislation to protect whistleblowers, such as the Protections for Persons Reporting Child Abuse Act 1998 in Ireland and the Notification and Federal Employee Antidiscrimination and Retaliation Act of 2002 in the US. Thus, the 1990s and 2000s saw whistleblowers receiving more protections, while secrecy clauses - such as requiring that malpractice be reported first internally - became more common in company contracts (Dworkin and Callahan 2008; Crowther and Capaldi 2008).

\section{Our understanding of whistleblowing}

For whistleblowing to occur there must be either an unlawful, or immoral, action (Dworkin and Baucus 1998). There are many different interpretations associated with 
the word whistleblowing. Bok (1980) defined whistleblowing as sounding an alarm within an organisation in which an individual works, aiming to highlight abuses that threaten the public interest. A decade later, Larmer (1992) defined whistleblowing as complaining, either within a corporation or publicly, about an organisation's unethical practices. Transparency International (TI) (2010) defines whistleblowing as "the disclosure of information about perceived wrongdoing in an organisation, or the risk thereof, to individuals or entities believed to be able to effect action."

Thus, the whistleblower can act internally, externally or with the assistance of a third party (Vandekerckhove 2006). Internal whistleblowing involves providing evidence to someone within the organisation - a line manager, or someone in human resources. External whistleblowing channels lie outside the organisation, such as law enforcement, or the media (Frederickson 1993). A third party includes such organisations as the IWB Neutral Third Party Whistleblowers Service, or Raiseaconcern.com.

Jubb (1999) found that the term whistleblowing contained six elements: an actor, disclosure subject, target, disclosure recipient, disclosure act and outcome. Alford (2001) classified the whistleblower as one who acts to prevent harm to others, trying first to resolve the situation within the framework provided by the organisation, while possessing evidence that would convince a sound person.

Vandekerckhove and Lewis (2011) highlight the importance of whistleblowers to a democracy. Leaks are essential in checking governmental, institutional and commercial power and in informing the public about policies and programmes (Papandrea 2014). As such, whistleblower legislation is a "guarantee for democracy and the well-being of society" (Crowther and Capaldi 2008, 189).

\section{Characteristics of whistleblowers}

Whistleblowers are usually individuals involved with, or employed by, an organisation, and their knowledge comes from their insider status. People who value fairness over loyalty are more likely to be whistleblowers (Waytz 2013). The problem is that while the act of whistleblowing can be seen as being honest, it can also be perceived as betrayal (Waytz 2013). Grant (2002, 391) described whistleblowers as tragic heroes; while for Lipman (2012) they are courageous individuals. "To be a whistleblower is to step outside the Great Chain of Being, to join not just another religion, but another world" (Alford 2001, 6).

Studies suggest that junior staff are more likely to be whistleblowers - they are not yet embedded in the organisational culture (Grove 2012; Shawver 2008). Although senior employees may suspect/be aware of misdemeanours, they are inclined to remain silent for fear of reputational damage, and tend to have more to lose. Hunt (2010) points out that women in general may be more inclined to whistleblow, as they tend not to be as deeply rooted in organisational culture as men. Rehg et al. (2008) examined gender and whistleblowing on a US Air Force base and found that after women came forward with allegations of malpractice, there were more reported incidents of retaliation against them. Henderson (2008) argues that gender bias means it is a battle for females to have the same power as their male counterparts. This lack of power leads to female whistleblowers suffering more than males (Ethics Resource Center 2012). 
Another factor is the amount of support the whistleblower feels he or she has. Rehg et al. (2008) stated that if the whistleblower has support from colleagues, they are less likely to experience retaliation. They also found that if a whistleblower encounters retaliation for reporting wrongdoing, they would be inclined to whistleblow to an external authority. Retaliation does not dissuade them from their ethical responsibility (Rehg et al. 2008).

\section{Motives behind whistleblowing}

Many whistleblowers' motivations relate to their morals. However, Jensen $(1997,78)$ points out that some whistleblowers are "engaging in a personal vendetta". Figg (2000) states that a whistleblower may make an issue public for fear of retaliation from an employer, or to prevent the firm from covering up the problem. However, he also argues that when the whistle is blown externally, personal and financial gain may be a motivation. If a whistleblower produces a great deal of negative press, a company may agree to provide them with an out of court settlement.

The debate on financial incentives for disclosing unethical activities is contentious. While some countries (US and China) believe rewards can aid in encouraging whistleblowers, others (the European Union (EU) and Australia) do not (DLA Piper 2013). Ireland does not provide financial incentives to whistleblowers.

Maranto (2013) identified four types of whistleblowers. Low-performing whistleblowers are unproductive employees who report malpractice to protect themselves. Megalomaniacs have a superior opinion of themselves, getting satisfaction from condemning colleagues. Machiavellian infighters feign public ethics for personal gain. Cornered whistleblowers do not look for trouble, but their ethical beliefs overcome loyalty to an organisation.

\section{Research methodology}

The in-depth interview is a qualitative technique that gives researchers an opportunity to gain an understanding of how others interpret their world. There are numerous strengths and weaknesses identified in the literature on using interviews (see Cohen, Manion, and Morrison 2000; Arksey and Knight 1999; Fontana and Frey 2000; Scheurich 1997). Interviews are a great means for investigating human experience, which suggests that the data provided can give an insight into the interviewee's recollection and understanding of events in an exploratory situation (Arksey and Knight 1999, 2-3). Our research involved an in-depth interview with Clonan in April 2015, and then combining the findings from this with material from documents he has written and media interviews he has given over the years.

Document analysis is often used in combination with other qualitative research methods, such as interviews or focus groups, as a means of triangulation, as the researcher is expected to draw upon multiple sources of evidence to seek convergence and corroboration (Bowen 2009, 28). As Flick (1992, 194) points out, such a strategy adds rigour, breadth, and depth to any investigation. We examined the documents produced by the Department of Defence and the Defence Forces that relate to the issues raised by 
Clonan. We made sure to employ a range of data sources in order to ensure the greatest accuracy in our findings and to reduce levels of ambiguity.

\section{Case study of a whistleblower - Dr Tom Clonan}

Dr Tom Clonan, formerly Captain Tom Clonan, constitutes what Maranto (2013) defines as a cornered whistleblower. These whistleblowers have ethical and moral beliefs and bring unethical issues to public attention. They do not necessarily look for trouble, but their honesty always overcomes their loyalty to the organisation.

Clonan joined the Artillery Corps at the age of 24, serving with the United Nations (UN) in trouble spots such as the Middle East and the former Yugoslavia. At the age of 31, he was brought back to Ireland where he was promoted to captain and worked for the Chief of Staff. In early 1999, Clonan began researching a doctoral thesis which focused on the status and roles assigned to female personnel in international military and terrorist organisations.

\section{Uncovering abuse}

The military authorities granted permission for the research, but imposed a number of conditions, including a provision that the findings "not be published" (Clonan 2010). Clonan's thesis involved interviewing 60 women in the Defence Forces - Army, Navy and Air Corps - in which only 123 women were employed at the time. Upon finishing the interviews, Clonan noticed that 59 of the interviewees said they had experienced some form of bullying, harassment, inappropriate touching, sexual assault and rape (RTE Radio 1 2013). They also disclosed that they had tried to report this to their superiors, but were not taken seriously (RTÈ Radio 1 2013).

Clonan was taken aback by what he had discovered. In November 2000, on completing his thesis, he informed the newly appointed Chief of Staff of his findings, but was told to give him a couple of months to "settle in" to his new job before exposing the information (Irish Independent 2007). Looking back, Clonan speaks of his naivety, "I thought I was going to get a medal" (NewsTalk 2013). But the Defence Forces did not seem to want to know about what he had found. As Kohn (2011) points out, most managers do not typically sing the whistleblowing employee's praise. In August 2001, a journalist from The Sunday World newspaper, gained access to the thesis and wrote a number of articles which brought its findings into the public domain (Clonan 2010).

\section{Negative impacts}

According to Jensen (1997), when it comes to whistleblowing many people tend to focus on the messenger and not the message. This can bring chaos to the whistleblower's life. Also, Irish attitudes towards whistleblowers were not always welcoming, with whistleblowers being treated with suspicion. This may have something to do with our colonial past and the fear of informers/collaborators. In Clonan's case, the Defence Forces decided to focus on him instead of on the information he was providing them with concerning the abuse of female personnel. Clonan felt the reaction to his research both from the military authorities and Department of Defence was extremely negative (Habimana 
2014). From the moment his findings entered the public domain, certain individuals within the Defence Forces began to attack his character. He went from being at the heart of the organisation to being someone who was vilified in public. Sercombe (2011) points to how it is vital for whistleblowers to build alliances and defences prior to going public in order to protect themselves. At one stage, Clonan received a phone call from a senior officer who explained that assassination of his character was the only way forward, closing the call with, "it is like a game of rugby, when you can't go for the ball, you go for the man” (RTÈ Radio 1 2013).

As highlighted by Donkin, Smith, and Brown (2008), retaliation faced by whistleblowers from their workplace is one of the most common consequences of their actions. Clonan experienced threatening phone calls, abusive text messages and emails, silent treatment, verbal harassment, whispering campaigns, physical assault, stress and loss of respect. This occurred at the hands of colleagues and superiors he had served with abroad and would have regarded as friends. "I felt very fearful as a whistleblower. I almost lost my job, livelihood and reputation. It was also very damaging professionally, personally and was very stressful and hurtful", Clonan affirmed (Habimana 2014). He said that he always felt he had to watch his back (Flynn 2015). For Clonan the worst aspects of his experience were the character assassination, retaliation and harm to his personal life (NewsTalk 2013).

One specific incident occurred in early 2001 when Clonan received a phone call from an officer in the Defence Forces Headquarters stating that the Chief of Staff wished to see him. Clonan thought that they may have finally accepted his findings. Instead, he was greeted by an officer with the words, "you are still not on about that women thing?" The meeting made clear that they did not care about his findings and he left the building with abuse being shouted after him. Clonan describes the event as the first time he realised there were going to be serious consequences for his working and personal life (RTE Radio 1 2013). It is the case that many whistleblowers experience loss of job, respect, trust, friends, psychological stress, loss of confidence of family and loved ones, and early retirement (see Ahern and MacDonald 2002; Wilmot 2000).

\section{Personal life}

Soeken and Soeken (1987) note that the impacts of whistleblowing do not stop at the whistleblower, but also impact their spouse and children. From 2001 to 2005, Clonan and his family were subjected to intimidation and harassment from former colleagues (Clonan 2010). Clonan (2014) explained how "with the trauma of losses of career and status, there is personal psychological distress and damage to relationships with significant others and even children."

In one incident, Clonan (2013) described a September day on Grafton Street, central Dublin, with his wife and son, when a former colleague approached him and verbally abused him. On another occasion, a phone call from a staff officer stated "there will be guerrilla warfare and every dirty trick in the book will be used against you, it's all your fault and you only have yourself to blame" (RTÈ Radio 1 2013). Clonan's new employer at the time also had reservations about employing him due to the allegations made against him by the Defence Forces in the newspapers. He felt people assumed he was a "loose cannon" because of his actions (RTÉ Radio 1 2013). Consequently, Clonan had a 
difficult time defending his reputation to the media and it took years for him to undo the damage the Defence Forces did (Clonan 2010).

When the Defence Forces continued to make false allegations against him, Clonan decided to get legal help. He sued the Army and the Minister for Defence for defamation (Clonan 2013; Habimana 2014). When the case finally came to court in 2005, Clonan explained how it was one of the most stressful times of his life, but that it almost felt therapeutic to stand up in court for what he knew was right (RTE Radio 12013 ).

\section{The importance of management for whistleblowers}

Donkin, Smith, and Brown (2008) highlight the importance of an organisation's management in dealing with whistleblowing, as they are often the first people in an organisation that the whistleblower reports to. When Clonan concluded his research as a serving army officer in November 2000, he advised a superior - in the most explicit terms - as to the nature of his findings. No action was taken. A few months later, in the spring of 2001, having retired from the Army the previous December, Clonan raised the matter again at Defence Forces headquarters. On that occasion, he admits that he was laughed at (Clonan 2005).

Clonan innocently believed at the time that "I was confident they would act on it his findings] immediately. I felt it would be greeted in a really positive manner" (RTE Radio 1 2013). Clearly, this was not the case. Donkin, Smith, and Brown (2008) explain how the treatment of a whistleblower by management has significant effects on whether the whistleblower views the outcome of their efforts in a positive or negative light. In Clonan's case, management did not want to know about his findings. The Defence Forces' response is arguably a classic example of how not to deal with a whistleblower.

Clonan (2014) also explained how the soldiers he interviewed experienced reprisals from the Defence Forces. He received emails from research participants - female soldiers, including commissioned officers - who stated that they had been the subject of much hostile scrutiny within the Defence Forces in the aftermath of the publication of his findings. One officer stated that she was convinced she had been passed over for a promotion due to her participation in Clonan's research (RTĖ Radio 12013 ).

Gallagher (2013) explains how creating an ethics policy and training for whistleblowing are key to improving ethical behaviour in an organisation. Managers must grasp a sound understanding of all aspects of whistleblowing, and once policies and procedures are in place, they have a duty to help employees see the value in consistently making ethical choices. Evidently, the Defence Forces were untrained with regard to whistleblowing and did not have any policy, or procedure, to follow when Clonan's findings came to light. Management is vital in curbing the negative effects for the whistleblower. But, the Defence Forces, in failing to adhere to any guidelines for dealing with whistleblowers, created a bigger problem for themselves.

Kaur (2012) points to the several issues that should be encompassed within a whistleblowing programme; prohibition of retaliation, top management must demonstrate the inclusion of whistleblowing in organisational culture and a commitment to whistleblowing policies, correct procedures must be in place to deal with whistleblowing complaints, and concerns must be communicated to employees to ensure everyone is of the same mind-set. Clonan believes that human resource managers should have a step-by-step guide for all 
individuals involved in a whistleblowing incident including the employer, the whistleblower, the person to whom the whistleblower reports and the person being accused of wrongdoing (Flynn 2015).

\section{The consequences of Clonan's whistleblowing}

Clonan's research, including his analysis of the Defence Forces' documents, laws and regulations, revealed an organisation with practices, policies and procedures that were explicitly discriminatory as they applied to female personnel. The findings also revealed an organisation out of step with the international military in terms of recruitment, training and deployment of female personnel (Clonan 2010). Galligan $(2000,79)$ in a report to the Department of Justice, Equality and Law Reform found that women made up an abnormally low 4 percent of the Defence Forces, a figure she remarked upon as "miniscule".

In October 2001, the then Minister for Defence initiated an independent enquiry into Clonan's findings by an External Advisory Group for the Defence Forces. This was at a time in Ireland where there were already enquiries being conducted into sexual abuse scandals within the Catholic Church and a broadening of the equality agenda (Curry 2003). The External Advisory Group reported in the spring of 2002 that Clonan's doctoral findings were valid (Clonan 2010). Their report, The Challenge of a Workplace, recommended policy changes related to harassment, workplace bullying, discrimination and sexual harassment (Doyle 2002).

King (2006) highlighted the positive changes in public policy that occurred due to Jeffrey Wigand taking on Brown \& Williamson Tobacco Corporation. A similar outcome occurred in the case of Clonan and the Defence Forces. In 2002, the Defence Forces produced a document entitled Defence Forces Policy on Interpersonal Relationships in the Defence Forces. This document refers to the issue of sexual harassment 32 times and bullying 31 times. Fifth section of the document is dedicated entirely to sexual harassment, defining it and providing examples so it can be identified and dealt with; while sixth section deals exclusively with bullying (Department of Defence 2002).

2002 also saw the establishment of the Independent Monitoring Group (IMG) to oversee the implementation of the recommendations contained in The Challenge of a Workplace and to provide ongoing monitoring of activities relating to gender equality. This group operated under the chairmanship of an external expert, Dr. Eileen Doyle, who had previously headed a government taskforce on bullying. In 2004, in response to Clonan's findings, and their own External Advisory Group's discoveries, the Defence Forces produced an equality mission statement and a comprehensive set of equality policies. Thus, the wider equality agenda was finally permeating into, and taking root within, the Defence Forces. This equality agenda had become embedded in Irish society from the 1970s onwards, particularly after joining the European Economic Community (EEC). Over the years between 1998 and 2015 there have been various Employment Equality Acts and Equal Status Acts introduced to provide for equal treatment, pay and conditions for men and women in the workplace and protections against discrimination in the provision of goods and services.

Part of this reform process, overseen by the then Minister for Defence, Willie O'Dea, saw the passing of the Ombudsman (Defence Forces) Act (2004), which provided the 
statutory authority for the appointment of an Ombudsman for the Defence Forces (appointed in 2006). "The legislation establishing the Office introduces civilian oversight into military complaint and grievance handling procedures" (Ombudsman for the Defence Forces 2006, 3). This represented a major change in how the Defence Forces were to build an inclusive culture, where whistleblowing was to be encouraged and facilitated, in order to develop a more democratic, inclusive and respectful organisational environment. Ireland was the first country in Europe to establish a dedicated, civilian Ombudsman for members of its Defence Forces. An Ombudsman for the public service had existed in Ireland since the early 1980s.

The first IMG (2004) report pointed to a number of issues that needed to be resolved in the Defence Forces, including problems related to equality and interpersonal behaviour. A member of this monitoring group was Major General James Sreenan, who in early 2004 became the army's chief of staff, and would thereafter oversee some of the changes needed to resolve these problems. Four years later, the second IMG (2008) report acknowledged that the Defence Forces had made progress on equality - with the appointment of an Equality Officer, and putting diversity and equality status policies in place. The Defence Forces also rewrote regulations and administrative instructions, and the human resources section has been expanded to provide a comprehensive support system - from contact persons to a confidentiality hotline and counselling service. This process was overseen by the Deputy Chief of Staff Major General Pat O'Sullivan. Two IMG reports (IMG 2008 and IMG 2014) both found that incidents of bullying and harassment had fallen significantly from the levels Clonan encountered, as can be seen in Table 1.

A 2007 report by TNS MRBI, commissioned by the Department of Defence, on the retention and recruitment of women in the Defence Forces, found that 11 percent of female personnel had, at some time in their service, experienced sexual harassment, a greatly reduced figure from that encountered by Clonan just eight years before. The Defence Forces changed their dignity charter to state "Bullying, sexual harassment and harassment in any form is NOT accepted by us and will NOT be tolerated" (Defence Forces 2011, 7). The third IMG (2014) report notes that the military also introduced mediation as an option at the informal stage for dealing with complaints and conflicts at work. It also records that under Chief of Staff, Lieutenant General Conor O'Boyle, the Defence Forces had undertaken gender awareness training and integrating a gender perspective into operations.

Table 1. Redress of wrongs.

\begin{tabular}{ccccc}
\hline & \multicolumn{4}{c}{ Bullying/harassment } \\
\cline { 2 - 5 } Year & Complaints & Upheld & Not Upheld & Withdrawn \\
\hline 2004 & 6 & 3 & 3 & 0 \\
2005 & 5 & 1 & 4 & 0 \\
2006 & 3 & 0 & 1 & 2 \\
2007 & 4 & 0 & 3 & 1 \\
2008 & 4 & 0 & 1 & 3 \\
2009 & 5 & 0 & 2 & 3 \\
2010 & 3 & 0 & 1 & 2 \\
2011 & 4 & 0 & 1 & 3 \\
2012 & 7 & 1 & 2 & 4 \\
2013 & 4 & 0 & 0 & 4 \\
\hline
\end{tabular}

Sources: IMG (2008), IMG (2014). 
The IMG (2014) report made 35 recommendations, one of which was an independently chaired review of progress related to dignity, bullying, harassment and sexual harassment in the Defence Forces. The government, and the then Minister for Defence Simon Coveney, were fully committed to ensuring the implementation of the IMG's (2014) recommendations (Department of Defence 2015).

In many respects, the Defence Forces, its various chiefs of staff and the government, in the wake of Clonan's whistleblowing, took the equality agenda further than many of their EU and North Atlantic Treaty Organisation (NATO) counterparts. Clonan (2010) points out that the policies put in place by the Irish Defence Forces are now considered a model of best practice in the international military community.

In an interview with the Irish Times in January 2009, Deputy Chief of Staff, Major General Ashe, reported that less than 1 percent of all serving personnel were reporting incidents of bullying or harassment (Clonan 2010). The number of women serving in the Defence Forces has more than quadrupled since Clonan conducted his research at the beginning of the century. This number stood at 559 in mid-2016, or just over 6 percent of all personnel - a level slightly below the international average (Ryan 2016). Consequently, in 2016 the then Minister for Defence announced that efforts would be made to double the percentage females serving in the Defence Forces by 2018 (Murtagh 2016). Also in 2016, in its strategy statement, the Department of Defence announced that a diversity and inclusion strategy was being developed for the defence forces (Department of Defence 2016). This comes at a time when the country is increasingly a multiracial and multicultural society.

Currently, the most senior female army officer is a colonel who was previously an infantry battalion commander (Murphy 2016); while the first female Naval Service captain was appointed in 2008 (Siggins 2010). All frontline combat roles were opened to Irish women many years before their US counterparts got the green light at the end of 2015 (Rosenberg and Philipps 2015). The most senior female line officers hold the rank of commandant equivalent to major in the US military.

The Defence Forces are also working on a gender mainstreaming process and fulfilling their commitments under United Nations Security Council Resolution 1325. Bastick (2014) notes that Ireland is one of only a small number of countries, including Belgium, the Czech Republic, Finland, Norway, South Africa and Spain that have a military action plan related to a "gender perspective" in their operations. Such a gender policy sets out goals and commitments in ensuring that a gender perspective is integrated into every policy and practice - focusing on equal opportunities for female personnel. Other countries, such as the Netherlands and Sierra Leone, have integrated gender issues into operations, such as dealing with sexual violence in conflict environments (Bastick 2014).

Kaur (2012) highlights how many whistleblowing stories end with a more honest organisation as a result. The Defence Forces, in the context of a changing society and under the influence of various monitoring groups, ministers for defence and chiefs of staff, transformed into a model organisation of best practice and high ethical standards, an organisation for other organisations, both commercial and public, in Ireland and overseas, to emulate. While these developments were taking place in the Defence Forces, legislation was also being introduced to protect whistleblowers in the wider society. The 2002 Competition Act offers protection to anyone reporting breaches of the Act and prohibits employers from penalising employees for doing so (Government of Ireland 2002). The 
Safety, Health and Welfare at Work Act 2005 provides protection against dismissal and penalisation of employees who, in good faith, take steps to protect themselves or others in a workplace situation (Byrne 2008). The statutory instrument Garda Síochàna Regulations 2007 contains mechanisms to enable members of the Garda Síochàna (police), or other individuals, to report in confidence allegations of wrongdoing within the force (Government of Ireland 2007). The Criminal Justice Act 2011 states that an employer cannot penalise or dismiss an employee for disclosing information to the appropriate authorities (Government of Ireland 2007). The Protected Disclosures Act 2014 introduced whistleblowing legislation encompassing all public and private sector bodies (Government of Ireland 2014). Under this legislation employees who are dismissed for whistleblowing could be rewarded with up to five years remuneration and the legislation seeks to assist the whistleblower in remaining anonymous. All public and private sector bodies must ensure their whistleblower procedures align with the legislation.

Clonan accepts that the military has reformed itself and improved significantly since the publication of his research. He says that "I am glad that the Army is a safer place to work for both men and women as a result of my research and my actions" (Habimana 2014). When asked if he would do it over, Clonan's response was

I have a wife and three sisters, I had to do the right thing. The Defence Forces is a better place because of the findings, and women are not suffering as they used to. As well as that, the guilt of not whistleblowing would have eaten away at me. I am happy that I did the right thing. (Flynn 2015).

"I swore an Oath of Allegiance to the Irish Constitution as an Army Officer. I did not swear loyalty to a bunch of sexist bullies at the Defence Forces Headquarters. And I have no regrets" (Habimana 2014). In terms of what advice he would proffer to potential whistleblowers, Clonan's response was “first get legal advice” (Flynn 2015).

\section{Conclusion}

At the turn of the century, when Clonan acted as a whistleblower, there were no legislative provisions in place to protect whistleblowers in Ireland. The Defence Forces had no procedures in place to deal with Clonan's allegations, nor was there much evidence of their interest in tackling the bullying and sexual harassment of female personnel he uncovered. As a result, negative consequences for whistleblowers were not unusual then. Nevertheless, Clonan's findings, and his determination to stand over those findings, had positive results for the military and for the women serving in it, as in the long run they were a catalyst for significant reforms. But, Clonan ended up sacrificing his army career and an easier life for one of harassment and ostracism at the hands of former colleagues and friends.

In the years since Clonan's findings became public there has been a great and ongoing effort within the military to build an ethical culture and one that is open to both internal and external audit. The work of the external advisory group in 2001 led to the establishment of the IMG in 2002, whose inaugural report was published in 2004, and has since been followed by reports in 2008 and 2014. These reports show ongoing improvements when it comes to gender equality in the Defence Forces. Simultaneously, the wider Irish societal context was one of increasing scrutiny concerning equality in general, and gender equality specifically, with a range of equality and equal status laws being introduced 
after the turn of the century. A number of laws were also passed that dealt with the protection of whistleblowers, culminating in the 2014 Protected Disclosures Act. Thus, the Defence Forces, in the context of a society undergoing liberal change, and under the guidance of various ministers for defence and chiefs of staff, has reformed its policies and procedures for dealing with bullying and sexual harassment and a range of other complaints and grievances. Equality policies are now a central pillar of the organisation, so much so that they are identified as being best practice. The number of female personnel in the military has increased significantly in the past decade (and is set to increase further), and women are now reaching senior officer ranks, in addition to serving in frontline combat roles.

Whistleblowers are vitally important in a democracy. Without their actions, abuse and corruption can go unchecked. Whistleblowers' activities can improve the organisations they work in and the wider society. However, the consequences for the whistleblowers themselves can be damaging. They can suffer emotional and physical abuse at the hands of former friends, colleagues, and associates, as well as see their careers ruined. This can impact their relationships, family life and emotional health. It seems that while the positive outcomes of whistleblowing for organisations and society are clear, they are much more difficult to discern for the whistleblowers themselves. In this respect, if legislation and ethical policies and procedures are put in place for acting on information obtained from whistleblowers, both the legal system and the organisations that they work for can play a role in protecting whistleblowers from retribution.

\section{Disclosure statement}

No potential conflict of interest was reported by the authors.

\section{Notes on contributors}

Grace Flynn is a graduate of the College of Business, Dublin Institute of Technology. Grace is interested in the topics of whistleblowing, and human resource management.

John Hogan is a Senior Research Fellow and Lecturer in Technological University Dublin (which was created in 2019 as an amalgamation of the Dublin Institute of Technology; Institute of Technology, Blanchardstown; and Institute of Technology Tallaght). He has published articles in international peer-reviewed journals, as well as books, chapters, newspaper articles, blogs, etc.

Sharon Feeney is a Senior Lecturer in Technological University Dublin with 30 years' experience in the tertiary education sector in Ireland and internationally. She is Deputy Chair of the Higher Education Authority, Ireland. Sharon has published numerous book chapters and journal articles in the areas of Teaching Innovation, Higher Education Policy, Student Experience in Higher Education and Quality Enhancement in Higher Education.

\section{References}

Ahern, Kathryn, and Sally MacDonald. 2002. "The Beliefs of Nurses Who Were Involved in a Whistleblowing Event." Journal of Advanced Nursing 38 (3): 303-309.

Alford, C. Fred. 2001. Whistleblowers: Broken Lives and Organizational Power. Ithaca, NY: Cornell University Press.

Anderson, Robert, Robert Perrucci, Dan Schendel, and Leon Trachtman. 1980. Divided Loyalties: Whistle-blowing at BART. West Lafayette: Purdue University Press. 
Arksey, Hilary, and Peter T. Knight. 1999. Interviewing for Social Scientists. London: Sage.

Barrera, Mario, and James Hughes. 2014. “Top 30 Whistleblowing Statutes - from Ralph Nader to Edward Snowden.” Globalworkplaceinsider.com, May 20. Accessed July 12, 2019. http://www. globalworkplaceinsider.com/2014/05/top-30-whistleblowing-statutes-from-ralph-nader-toedward-snowden/.

Bastick, Megan. 2014. Integrating a Gender Perspective Into Internal Oversight Within Armed Forces. Geneva: DCAF/OSCE/ODIHR.

Bjørkelo, Brita, and Ole Jacob Madsen. 2013. "Whistleblowing and Neoliberalism: Political Resistance in Late Capitalist Economy." Psychology \& Society 5 (2): 28-40.

Bok, Sissela. 1980. "Whistleblowing and Professional Responsibility." New York University Education Quarterly 11 (1): 2-10.

Bowen, Glenn A. 2009. "Document Analysis as a Qualitative Research Method." Qualitative Research Journal 9 (2): 27-40.

Byrne, Raymond. 2008. Safety, Health and Welfare at Work Law in Ireland. Dublin: Nifast.

Carroll, Archie, and Ann Buchholtz. 2014. Business and Society: Ethics, Sustainability, and Stakeholder Management. 9th ed. Stamford, CT: Cengage Learning.

Clonan, Tom. 2005. "Dr Tom Clonan Replies to Eoghan Harris." Irish Independent, June 19. Accessed June 12, 2019. http://www.independent.ie/opinion/letters/dr-tom-clonan-replies-toeoghan-harris-26209486.html.

Clonan, Tom. 2010. "Researcher as a Whistleblower: The Ethical Challenges Posed by Sensitive Research.” Paper Presented at the Interdisciplinary Conference on Ethics and The Academy, Salzburg, September 2-4. Accessed July 12, 2019. https://arrow.dit.ie/aaschmedart/44/.

Clonan, Tom. 2013. Whitlerblower, Soldier, Spy: A Journey Into the Dark Heart of the Global War on Terror. Dublin: Liberties Press.

Clonan, Tom. 2014. "We Need to Tackle Culture of Whistleblower Reprisal.” The Irish Times. April 21. Accessed July 13, 2019. http://www.irishtimes.com/news/politics/we-need-to-tackle-cultureof-whistleblower-reprisal-1.1768235.

Cohen, Louis, Lawrence Manion, and Keith Morrison. 2000. Research Methods in Education. 5th ed. London: Routledge/Falmer.

Crowther, David, and Nicolas Capaldi. 2008. The Ashgate Research Companion to Corporate Social Responsibility. Aldershot: Ashgate.

Curry, John. 2003. Irish Social Services. 4th ed. Dublin: Institute of Public Administration.

Defence Forces. 2011. Defence Forces Information Handbook. Dublin: Defence Forces Headquarters. Accessed July 26, 2019. https://web.archive.org/web/20170828204953/http:// www.military.ie/fileadmin/user_upload/images/Info_Centre/documents/DF_Info_Handbook_ layout_low_res.pdf.

Department of Defence. 2002. Defence Forces Policy on Interpersonal Relationships in the Defence Forces. Dublin: Department of Defence. Accessed July 26, 2019. https://web.archive.org/web/ 20170426084221/http://www.defence.ie/WebSite.nsf/72804bb4760386f380256c610055a16b/ 72a7af1fd50bffe5802570ff005846b4/\$FILE/DF\%20Policy\%20on\%20Relationships.htm.

Department of Defence. 2015. White Paper on Defence. Dublin: Department of Defence. Accessed July 23, 2019. https://www.defence.ie/system/files/media/file-uploads/2018-06/wp2015eng_1. pdf.

Department of Defence. 2016. Department of Defence and Defence Forces Strategy Statement 20162019. Dublin: Department of Defence. Accessed July 26, 2019. https://web.archive.org/web/ 20170425194034/http://www.defence.ie/website.nsf/Strategy2016aE.

Devine, Tom, and Tarek F. Maassarani. 2011. The Corporate Whistleblower's Survival Guide: A Handbook for Committing the Truth. San Francisco, CA: Berrett-Koehler Publishers.

DLA PIPER. 2013. Whistleblowing: An Employer's Guide to Global Compliance. DLA PIPER. Accessed July 23, 2019. https://www.dlapiper.com/en/norway/insights/publications/2013/11/ whistleblowing-an-employers-guide-to-global-com__/.

Donkin, Marika, Rodney Smith, and A. J. Brown. 2008. "How Do Officials Report? Internal and External Whistleblowing." In Whistleblowing in the Australian Public Sector, edited by A. J. Brown, 83-108. Canberra: ANU E Press. 
Doyle, Eileen. 2002. The Challenge of a Workplace. Dublin: Department of Defence.

Dworkin, Terry Morehead, and Melissa S. Baucus. 1998. "Internal vs. External Whistleblowers: A Comparison of Whistleblowing Processes." Journal of Business Ethics 17 (12): 1281-1298.

Dworkin, Terry Morehead, and Elletta S. Callahan. 2008. "Buying Silence." American Business Law Journal 36 (1): 151-191.

Ethics Resource Center. 2012. Retaliation: When Whistleblowers Become Victims. Ethics Business Center. Accessed July 15, 2019. http://jpp.whs.mil/Public/docs/03_Topic-Areas/06-Retaliation/ 20150410/06_ERC_RetaliationWhenWhistleblowersBecomeVictims.pdf.

Figg, Jonathon. 2000. "Whistleblowing." Internal Auditor 57 (2): 30-37.

Flick, Uwe. 1992. “Triangulation Revisited: Strategy of Validation or Alternative?” Journal for Theory of Social Behaviour 22 (2): 175-198.

Flynn, Grace. 2015. "Don't Shoot the Messenger ... You Might Miss the Message - A Look into the Life of a Whistleblower." Unpublished thesis. College of Business, Dublin Institute of Technology.

Fontana, Andrea, and James H. Frey. 2000. "The Interview: From Structured Questions to Negotiated Text." In A Handbook of Qualitative Research, 2nd ed., edited by Norman K. Denzin and Yvonna S. Lincoln, 645-672. Thousand Oaks, CA: Sage.

Frederickson, H. George. 1993. Ethics and Public Administration. Armonk, NY: M.E. Sharpe.

Gallagher, Chuck. 2013. "Whistleblowing: How to Build a Culture of Ethics." Leadership Excellence 30 (11): 21.

Galligan, Yvonne. 2000. The Development of Mechanisms to Monitor Progress in Achieving Gender Equality in Ireland. Dublin: The Stationary Office.

Glazer, Myron Peretz, and Penina Migdal Glazer. 1989. The Whistleblowers: Exposing Corruption in Government and Industry. New York: Basic Books.

Government of Ireland. 2002. Competition Act 2002. Dublin: Electronic Irish Statute Book. Accessed July 29, 2019. http://www.irishstatutebook.ie/eli/2002/act/14/enacted/en/pdf.

Government of Ireland. 2007. S.I. No. 214/2007 - Garda Síochána (Discipline) Regulations 2007. Dublin: Electronic Irish Statute Book. Accessed July 29, 2019. http://www.irishstatutebook.ie/ eli/2007/si/214/made/en/print.

Government of Ireland. 2011. Criminal Justice Act 2011. Dublin: Electronic Irish Statute Book. Accessed July 29, 2019. http://www.irishstatutebook.ie/eli/2011/act/22/enacted/en/html.

Government of Ireland. 2014. Prikotected Disclosures Act 2014. Dublin: Electronic Irish Statute Book. Accessed July 29, 2019. http://www.irishstatutebook.ie/eli/2014/act/14/enacted/en/print\#part1.

Grant, Colin. 2002. "Whistle Blowers: Saints of Secular Culture." Journal of Business Ethics 39 (4): 391-399.

Grove, Jack. 2012. "Make It Easier to Whistleblow While You Work." The Times Higher Education Supplement, January 10. Accessed July 22, 2019. https://www.timeshighereducation.com/news/ make-it-easier-to-whistleblow-while-you-work/418745.article.

Habimana, Seraphine. 2014. "Whistleblower, Soldier, Spy." Campus.ie, December 4. Accessed June 19, 2019. http://campus.ie/surviving-college/college-news/whistleblower-soldier-spy.

Henderson, Mary U. 2008. "Women Whistleblowers in the Workplace." PhD diss., University of St. Thomas, Minneapolis, Minnesota.

Hunt, Linda. 2010. “The Challenges Women Whistleblowers Face.” International Business Research 3 (2): 3-8.

IMG. 2004. Response to the Challenge of a Workplace. Dublin: Defence Forces Printing Press.

IMG. 2008. Second Report of the Independent Monitoring Group. Dublin: Defence Forces Printing Press. Accessed July 23, 2019. https://health.gov.ie/wp-content/uploads/2014/03/vision_for_ change_2nd_report.pdf.

IMG. 2014. Third Report of the Independent Monitoring Group. Dublin: Defence Forces Printing Press. Accessed July 23, 2019. https://www.defence.ie/system/files/media/file-uploads/2017-12/ img32014.pdf.

Irish Independent. 2007. “Army Knew of Sex Abuse for Years”. Irish Independent, September 2. Accessed July 23, 2019. http://www.independent.ie/irish-news/army-knew-of-sex-abuse-foryears-26315251.html. 
Jensen, John Vernon. 1997. Ethical Issues in the Communication Process. Mahwah: Erlbaum. Jubb, Peter B. 1999. "Whistleblowing: A Restrictive Definition and Interpretation." Journal of Business Ethics, 21 (1): 77-94.

Kaur, Chanjyot. 2012. "Whistle Blowing: An Anti-corruption Tool." International Journal of Advanced Research in Management and Social Sciences 1 (5): 48-63.

King, Granville. 2006. "Image Restoration: An Examination of the Response Strategies Used by Brown and Williamson After Allegations of Wrongdoing." Public Relations Review 32 (2): 131-136.

Kohn, Stephen. 2011. Whistleblower's Handbook: A Step-by-step Guide to Doing What's Right and Protecting Yourself. Gilford: Lyons Press.

Larmer, Robert A. 1992. "Whistleblowing and Employee Loyalty." Journal of Business Ethics 11 (2): 125-128.

Lipman, Frederick. D. 2012. Whistleblowers: Incentives, Disincentives, and Protection Strategies. Hoboken: Wiley.

Maranto, Robert. 2013. "Thinking About Whistleblowers: Their Motives Vary - The Boss' Response Does Not.” The Huffington Post. November 11. Accessed July 23, 2019. http://www. huffingtonpost.com/robert-maranto/thinking-about-whistleblo_b_3830426.html.

Miceli, Marcia P., and Janet P. Near. 1984. "The Relationships among Beliefs, Organizational Position, and Whistle-blowing Status: A Discriminant Analysis." Academy of Management Journal 27 (4): 687-705.

Miceli, Marcia P., Janet P. Near, and Terry M. Dworkin. 2008. Whistle-blowing in Organizations. New York: Routledge.

Murphy, Darragh. 2016. “Meet the Defence Forces' First Female Colonel.” Thejournal.ie, July 7. Accessed July 23, 2019. http://www.thejournal.ie/irish-army-women-2-2867102-Jul2016/.

Murtagh, Peter. 2016. "Defence Forces Target 'Sporty Females' for Recruitment." The Irish Times, April 14. Accessed July 23, 2019. http://www.irishtimes.com/news/ireland/irish-news/defenceforces-target-sporty-females-for-recruitment-1.2609691.

Nader, Ralph, Peter J Petkas, and Kate Blackwell, eds. 1972. Whistle Blowing: The Report of the Conference on Professional Responsibility. New York: Grossman Publishers.

NewsTalk. 2013. “Tom Clonan: 'Whistleblower, Soldier, Spy'.” The Pat Kenny Show. Accessed July 15, 2019. https://www.newstalk.com/podcasts/highlights-from-the-pat-kenny-show/tomclonan-34-whistleblower-soldier-spy-34.

Ombudsman for the Defence Forces. 2006. Ombudsman for the Defence Forces Annual Report. Dublin: Defence Forces Headquarters. Accessed June 3, 2019. http://www.odf.ie/publications/ ODFReport-EnglishOnly.pdf.

Papandrea, Mary-Rose. 2014. "Leaker Traitor Whistleblower Spy: National Security Leaks and the First Amendment." Boston University Law Review 94 (2): 449-544.

Payne, Brian K. 2013. White Collar Crime: The Essentials. Washington, DC: Sage.

Rehg, Michael T., Marcia P. Miceli, Janet P. Near, and James R. Van Scotter. 2008. “Antecedents and Outcomes of Retaliation Against Whistleblowers: Gender Differences and Power Relationships.” Organization Science 19 (2): 221-240.

Rosenberg, Mathew, and Dave Philipps. 2015. “All Combat Roles Now Open to Women, Defense Secretary Says”. The New York Times. December 3. Accessed July 3, 2019. https://www.nytimes. com/2015/12/04/us/politics/combat-military-women-ash-carter.html.

RTÈ Radio 1. 2013. Whistleblowers, August 1. Accessed July 15, 2019. http://www.rte.ie/radio1/ whistleblowers/programmes/2013/0801/465980-whistleblowers-programmes-01082013$000000 /$ ? clipid $=1280803$.

Ryan, Jennifer. 2016. “In the Army Now: What's Life Like for Women?" The Irish Times, July 4. Accessed July 15, 2019. http://www.irishtimes.com/life-and-style/people/in-the-army-nowwhat-s-life-like-for-women-1.2705571.

Scheurich, James Joseph. 1997. Research Method in the Postmodern. London: Falmer.

Sercombe, Howard. 2011. Youth Work Ethics. London: Sage.

Shawver, Tara. 2008. "What Accounting Students Think About Whistleblowing." Management Accounting Quarterly 9 (4): 33-40. 
Siggins, Lorna. 2010. "First Female Commanding Officer in Naval Service Bids Farewell to Crew." The Irish Times, November 12. Accessed July 15, 2019. http://www.irishtimes.com/news/firstfemale-commanding-officer-in-naval-service-bids-farewell-to-crew-1.676139.

Soeken, Karen L, and Donald R. Soeken. 1987. A Survey of Whistleblowers: Their Stressor and Coping Strategies. Paper, University of Maryland. Accessed July 20, 2019. http://www. whistleblower-net.de/pdf/Soeken.pdf.

TNS MRBI. 2007. Retention and Recruitment of Women in The Defence Forces. Accessed 25 July 2019. https://slideplayer.com/slide/4803254/.

Tracy, Michael W. 2006. "Whistleblowing in Corporate America: Organizational Factors and Their Influence on the Employee Decision-making Process." $\mathrm{PhD}$ diss., Walden University, Minneapolis.

Transparency International. 2010. Whistleblowing: An Effective Tool in the Fight Against Corruption. Accessed July 15, 2019. http://transparency.ie/sites/default/files/TIWhistleblowing.pdf.

Vandekerckhove, Wim. 2006. Whistleblowing and Organisational Social Responsibility: A Global Assessment. London: Ashgate.

Vandekerckhove, Wim. 2010. "Whistleblowing: Perennial Issues and Ethical Risks." In A Hanbook of Corporate Governance and Social Responsibility, edited by Guler Aras and David Crowther, 521-538. Farnham: Gower.

Vandekerckhove, Wim, and Dave Lewis, eds. 2011. Whistleblowing and Democratic Values. London: The International Whistleblowing Research Network. Accessed July 21, 2019. http:// www.academia.edu/1348441/Whistleblowing_and_Democratic_Values_free_ebook.

Waytz, Adam. 2013. "What Makes a Whistleblower?" Hereandnow.org, August 12. Accessed July 15, 2019. http://hereandnow.wbur.org/2013/08/16/whistleblowing-fairness-loyalty.

Wilmot, Stephen. 2000. "Nurses and Whistleblowing: The Ethical Issues." Journal of Advanced Nursing 32 (5): 1051-1057. 